\title{
Computational Thinking Integration Strategy for the Urban Middle School Classroom
}

\author{
Lauren Birney $^{1} \&$ Denise McNamara ${ }^{2}$ \\ ${ }^{1}$ School of Education, Pace University, New York, USA \\ ${ }^{2}$ School of Education, The College of Staten Island, Staten Island, USA \\ Correspondence: Lauren Birney, School of Education, Pace University, 1 Pace Plaza, New York 10038, USA. Tel: \\ 212-346-1323.
}

Received: July 11, 2018

doi:10.5430/irhe.v3n3p51
Accepted: July 31, 2018

Online Published: August 30, 2018

URL: https://doi.org/10.5430/irhe.v3n3p51

\begin{abstract}
This article provides an overview of the work pioneered by the consortium of collaborators in the Billion Oyster Curriculum and Community Enterprise for Restoration Science Project (BOP-CCERS). The BOP-CCERS are working to support computational thinking in the New York City public school classrooms by creating curriculum which combines:

1. The Field Station Research (Oyster Restoration Stations) and data collection

2. The Billion Oyster Project Digital Platform and data input and storage

3. The New York State Science Intermediate Level Learning Standards.

4. The Computer Science Teachers Association K-12 Computer Science Standards

The integration of computational thinking in the STEM middle school classroom is showcased through the intertwining of these dimensions into a trans-disciplinary learning experience that is rich in both content and practice. Students will be able to explain real-world phenomena found in their own community and design possible solutions through the key components of computational thinking.

The Curriculum and Community Enterprise for Restoration Science Project digital platform and curriculum will be the resources that provide the underpinnings of the integration of computational thinking in the STEM middle school classroom. The primary functions of the platform include the collection and housing of the data pertaining to the harbor and its component parts, both abiotic and biotic and the storage of the curriculum for both the classroom and the field stations.
\end{abstract}

Keywords: computational thinking, restoration science, digital platform, computer science

\section{Introduction}

The term conceptual thinking has been incorporated into the education vernacular in recent years. In fact, the Next Generation Science Standards use this term quite freely in describing the problem solving approach needed by students in the $21^{\text {st }}$ Century. Jeanette Wing (2006) stated that computational thinking is the "general analytic approach to problem solving and designing systems through a set of thinking skills, habits and approaches". She saw a need for an effective means of processing data through her work as a professor of Computer Science at Carnegie Mellon University.

In simplest terms, computational thinking is the way humans solve problems. To enhance this problem solving, computers are needed to "build systems with functionality limited only by our imaginations" (Wing, 2006). Human thought is extended by combing computational thinking with computers. This has become an indispensable part of our everyday lives and work (Barr, Harrison \& Conery, 2011). Computational thinking is a problem solving process composed of four stages:

- Decomposition - Breaking a problem into manageable chunks to make it easier to solve.

- Pattern Recognition - Seeing a generalized view of the problem; trends or regularities in the data

- Abstraction - Finding the general principles that generate the patterns in the data 
- Algorithm design - Developing the step-by-step instructions to solve this problem and others like it.

Due to the continual rise in information and the abundance of data created, the ability to translate this information into palpable portions is tantamount in being able to solving real world problems. Arming students with this skillset has compelled a change in the way computer science is taught in the p-12 educational system. According to Waterford Technologies (Note 1), ninety percent of the data in the world today has been created in the last two years alone. Learning to respond to this enormous amount of information and determine the validity and use is paramount preparing students for a realistic view of the $21^{\text {st }}$ century skills needed (Cassel \& Kolstad, 1998).

\section{Partnerships and the New York City School System}

The educational response to the changing technological landscape came in the fall of 2015 in New York City. The Equity and Excellence Agenda was initiated and one of the cornerstones of the agenda is Computer Science for All (CS4All). Highlights include the addition of at least one full year of computer science for all students in elementary, middle school and high school. The goal is to have students learn to think with the computer by utilizing computational thinking, problem-solving, creativity and critical thinking (New York City Department of Education, 2018). This addition to the largest school system in the United States is the result of several studies showing the imperative for computer science and technological studies. In a study by Curzon, et al, 2014, it was found that pupils (in computer science classes) develop a unique way of thinking about and solving problems while gaining pertinent knowledge.

Another component of the Computer Science for All (CS4All) initiative in New York City is the on-going professional development of over 5,000 teachers in computer science who will bring computer science education to the city's 1.1 million students. To accomplish this monumental task, a number of partnerships needed to be developed through a range of foundations and institutes of higher education. One such partnership is the one created between the New York City Department of Education's Computer Science Department and the Billion Oyster Project-Curriculum and Community Enterprise for Restoration Science in New York Harbor (BOP-CCERS).

2.1 The Billion Oyster Project-Curriculum and Community Enterprise for Restoration Science in New York Harbor (BOP-CCERS)

The BOP-CCERS Project is an expansive place-based environmental education effort to being conducted in the schools in New York City (Birney \& McNamara, 2017a). Implementing this ambitious model in the nation's largest and most diverse school district (1.1 million students) provides an extraordinary opportunity for increasing access to high quality STEM education in under-performing schools and broadening participation in STEM career fields from within historically underrepresented communities. To establish a more diverse STEM workforce, there is a need to boost student interest in community-based citizen science. The persistent call for 21 st century skill development includes learning and innovation skills derived from critical thinking, which will help New York City Public school students to fill the STEM jobs of the future (Trilling \& Fadel, 2009).

The Billion Oyster Project is a real-world learning model that is multidisciplinary, experiential and situated in a community that is home to 8.5 million humans and innumerable aquatic life and other terrestrial organisms. As its name implies, the focus of the Billion Oyster Program is to introduce a billion oysters back into New York Harbor. To date, there are 19.5 million oysters restored to the estuary known as New York Harbor. This has been a prodigious endeavor in and of itself. To add the component of educational goals and future STEM employment opportunities shows the full breadth of the project's undertaking.

Two key components of the BOP-CCERS program are its signature restoration science-based STEM education for middle-school students and the teacher training model for New York City public schools. The teacher training component of BOP-CCERS Phase 2 will draw on the most relevant concepts and practices of the K-12 Computer Science Framework, with an emphasis on those areas where Computer Science integrates seamlessly with New York State P-12 Science Learning Standards, specifically the Core Concepts of Data Interpretation and Analysis, and the following Core Practices:

\section{- Define problems}

S1. Ask questions and define problems (National Research Council, 2012)

M1. Make sense of problems and persevere in solving them (from Common Core Math standards)

CS3. Recognizing and Defining Computational Problems

\section{- Use computational thinking}

S5. Use mathematics and computational thinking (National Research Council, 2012) 
CS3. Recognizing and Defining Computational Problems

CS4. Developing and Using Abstractions

CS5. Creating Computational Artifacts

\section{- Communicate with data}

S4. Analyze and interpret data (National Research Council, 2012)

CS7. Communicating About Computing

\subsection{Development of the New York State Science Learning Standards}

In April 2013, the K-12 Next Generation Science Standards were unveiled after an arduous and thorough developmental process. The need for the United States to initiate national science standards had been long and overdue. It began as far back as the successful mission of the Soviet Union's Sputnik in 1957. The urgency was realized when it was seen that nation was failing to keep up with the rest of the world in terms of science and mathematical human capital. In 1983, the National Commission on Excellence in Education published a report entitled, A Nation at Risk, which outlined the American school systems' failure to educate and the country's overall underachievement in terms of national and international gauges. One such gauge that gave further credence to this line of thought is the Program for International Student Assessment (PISA) study employed by the Organization for Economic Cooperation and Development (OECD). It is an assessment used to measure 15-year-old students scholastic scores in mathematics and science. The United States is consistently outranked by other countries in these assessments to the alarm of all of the stakeholders in the science field. The United States ranked 40/72 countries in mathematics and 25/72 countries in science (PISA, 2015). The concern was not only on the level of education but also on how this impacted the human capital needed to boost economic growth in the United States. Of the students that enter universities with an interest in STEM, only $40 \%$ finish with a STEM degree. In terms of under-represented students, the percentage drops to $20 \%$ (PCAST STEM Undergraduate Working Group, 2012). All major stakeholder had deep seeded and realistic concerns about the state of science and mathematics (now known as Science, Technology, Engineering and Mathematics). It was decided that a set of national science standards would be developed to begin to reverse the direction of this movement and even the educational playing field.

The National Research Council (NRC) began its work by developing the Frameworks for K-12 Science Education (NRC, 2012). By convening experts in the field of education and science, four major components in science were developed: physical science, life science, earth \& space science and engineering. Each of these components was appropriately spiraled and specified the science all K-12 students should know. Building from this document, state leaders the development of the K-12 standards under the guidance of Achieve, Inc. The standards that were developed are much larger in scope and depth that any previous work and are actually a set of performance expectations. The standards are structured to include three dimensions of learning (science and engineering practices, disciplinary core ideas and crosscutting concepts) that lead to a performance expectation the every science student is expected to achieve. The final product, the K-12 Next Generation Science Standards went through several reviews by all stakeholders. In April 2013 the standards were released and ready for state adoption. Each state had the choice of adopting or adapting the standards. The New York State Department of Education had a robust set of science standards and decided to adapt the standards to enhance its existing benchmarks.

In January 2015, New Yew York State Board of Regents approved a statewide Strategic Plan for the development and adoption of the P-12 New York State Science Learning Standards (NYSSLS). Through the work of the Science Education Steering Committee and the Science Standards Writing Team, the standards were drafted, posted for public review, revised and then adopted in July 1, 2017. Similar in format to the NGSS, there are three dimensions to the standards and the culminating performance expectation for each major concept in the four areas of science. Of major importance in the NYSSLS are the embedded practices that the students must be able to achieve such as analyzing and interpreting data and using mathematical an computational thinking (NGSS, 2013; NYSSLS, 2017)

\subsection{Science, Technology, Engineering and Mathematics (STEM) Education}

One of the key components of science and mathematics education is computational thinking and reasoning with data (Morris, Masnick, Baker \& Junglen, 2015). Science and Mathematics education has been undergoing a massive transformation in the last few decades. A new scientific paradigm, e-Science, is emerging, where computing techniques are an essential part of every step in the scientific workflow (Borgman, 2007; Hey \& Trefethen, 2005). The driving force behind these changes is the shift in focus in the global community. Major transformations in the way science and mathematics, or on a broader scale, Science, Technology, Engineering and Mathematics is 
approached in the occupational arena has forced the hand of the educational community to capitulate and fucus on $21^{\text {st }}$ Century skills. By the year 2020, one in every two jobs in the STEM fields will involve computing or computational thinking (Weintrop, et al, 2016).

Much has been written about the skills that will be needed for the $21^{\text {st }}$ century. The educational community has been inundated with learning expectations "for all", an all-inclusive drive that focused on global well-being and individual mobility. In April of 2010, President Obama addressed the National Academy of Science and stated unequivocally that the United States would ". . . . move from the middle of the pack to the top of the pack in science and mathematics within the next decade. The key to meeting these challenges - to improving our health, to harnessing clean energy, to protecting our security, and succeeding in the global economy - will be reaffirming and strengthening America's role as the world's engine of scientific discovery and technological innovation." The demand for a workforce that can survive in an ever-changing technological environment is similar to zeroing in on an ever changing target or planning for future unknowns - a perfect storm as it were. However, the continual consensus is the need for critical thinking - the ability to pull a problem apart, view it from a multitude of perspectives and create a design to solve societal issues with new and innovative approaches - or what can be best described as computational thinking. As considered by Sneider, et al. in 2014, increased computational thinking abilities the students develop will encourage them to pursue science, technology, engineering, and mathematics in college and possibly as a career.

As stated by Allan, et al in 2011, there are many challenges attached to implementing computational thinking during the school day. Some of the obvious factors impeding this inclusion include mandatory curriculum standards, the lack of opportunities for teachers to learn computational thinking and the lack of access to necessary infrastructure. The one constant that exists, regardless of the problem or challenge, is a student's ability to think critically to solve problems, make decisions and interact with our world (Kules, 2016). The inclusion of the BOP-CCERS curriculum allows for computational thinking to occur in the classroom while meeting the curricula challenges mentioned.

BOP-CCERS begins with the vision that public school curricula, particularly in the STEM fields, is enhanced by explicitly linking teaching and learning to a localized, large-scale environmental restoration endeavor that demands authentic research, the meticulous collection of data and related experimentation. Connecting student learning to place is a way to motivate science learning, rouse underrepresented communities, and galvanize the connection between the school curriculum and students' lived experiences (Calabrese-Barton \& Berchini, 2013). Education is no longer defined as a series of subject specific content that must be acquired, but rather, a real world integration of all content as it relates to actual situations that challenge society both on the larger scale and more locally (Birney \& McNamara, 2017b). A new emphasis has been placed on authentic investigations that include eight scientific practices (NGSS, 2013; New York State P-12 Science Learning Standards, 2017), one of which is "using mathematics and computational thinking" (Weintrop, et al, 2016) In New York City, there are numerous local environmental problems that merit inquiry-based science research by students; however, none is more fundamental than the question of human impact on our waterways. A key component of the BOP-CCERS Project is remediation to reverse the environmental damage done to the waters of New York Harbor. Statistical information involving the community and its members, the usage of the curriculum and the expeditions to the restoration stations are all located on the digital platform which is freely accessible to the members of the BOP-CCERS community. Sobel (2005) states that by investigating community issues in education, there is a notable increase in academic achievement with students developing stronger bonds to their community. This enhances students' appreciation for the natural world and creates an intensified commitment to serve as active citizen scientists.

\section{Integrating Computational Thinking in the Middle School BOP-CCERS Science Classroom}

An example of the incorporation of computational thinking in the middle school BOP-CCERs curriculum can be seen in the following lesson found on the BOP Digital Platform (See Appendix A).

Lesson Title: Nitrogen Cycle Part 8- Use the Digital Platform to Study Nitrogen throughout Our Estuary

Summary:

Prior Knowledge:
This lesson is taught with the $5 \mathrm{E}$ model and as a part of a series of lessons in the unit titles Nitrogen Investigation. In this lesson, students are asked to refer to the digital platform (https://platform.bop.nyc/lessons) to access ammonia $\left(\mathrm{NH}_{3}\right)$ and nitrate $\left(\mathrm{NO}_{3}^{-}\right)$information through a data search from the number of Oyster Restoration Stations throughout New York Harbor.

Students have already worked with the digital platform to find Oyster Restoration Station (ORS) data and compile this into excel spreadsheets. 
Students have learned the nitrogen cycle and understand the meaning of ammonia and nitrate levels in the water.

Students understand the significance of threshold levels of ammonia and nitrites in the estuary water at the ORS sites and its effect on the health of the estuary and its biotic/abiotic components.

\section{Standards Addresses:}

\section{New York State P-12 Science Learning Standards, 2017:}

MS-LS2-1. Analyze and interpret data to provide evidence for the effects of resource availability on organisms and populations of organisms in an ecosystem. [Clarification Statement: Emphasis is on cause and effect relationships between resources and growth of individual organisms and the numbers of organisms in ecosystems during periods of abundant and scarce resources.]

CSTA K-12 Computer Science Standards, 2017:

2-DA-08, Grades 6-8:

Collect data using computational tools and transform the data to make it more useful and reliable.

2-DA-09, Grades 6-8:

Refine computational models based on the data they have generated.

2-AP-10, Grades 6-8:

Use flowcharts and/or pseudo-code to address complex problems as algorithms.

A major component of the lessons in the Nitrogen Cycle Unit is the decision-making skills required by the students. This provides students with a framework for learning content that is meaningful and enriching. In addition, students are encouraged to collaborate with one another throughout each step of the activity. A study done by Brennan and Resnick (2012), found that conversations about their work engage young people in a meta-cognitive activity, encouraging them to think about their thinking, a capacity important to developing as a self-regulating learner. In addition, one of the core $21^{\text {st }}$ Century Learning and Innovation skills is collaboration (Partnership for $21^{\text {st }}$ Century Learning, 2016).

The students must decide the following:

1. The location of each of the ORS sites using longitude and latitude coordinates and the following website: https://www.gps-coordinates.net/

2. Which ORS sites they would like to include in their study

3. The usefulness of each of the parameters on the excel spreadsheet in the ammonia - nitrate investigation.

4. The algorithm for the selected data and how to interpret meaning.

5. The interpretation of the data they have selected for the investigation. (Evidence for the effects of resource availability on organisms and populations of organisms in an ecosystem).

6. The communication of their findings to the larger community (class, school, ORS community) including possible solutions for the harmful ammonia/nitrate combinations at certain ORS sites.

Once the students have selected the Oyster Restoration sites for the activity, they must download all of the pertinent information found at each site (See Figure 3). There are approximately twenty-two categories of information for each of the sites and the students must begin by selecting the information they feel will be needed to make a correlation between the availability of resources and its effects on the organisms at the particular ORS site. Much of their decision making is based on their prior knowledge gained through their sequential exposure to the ORS sites, the BOP Platform and the science content knowledge found in the middle school curriculum and the ORS protocols. The development of a computational model of a physical phenomenon involves many of the pertinent aspects of computational thinking (Sengupta, Kinnebrew, Basu, Biswas \& Clark, 2013).

\subsection{Nitrogen Cycle - Part 8}

Using the data base of all of the Oyster Restoration Sites (ORS) that collected information in July 2017 (See Figure 1), the students filter the information that they feel is pertinent to their investigation and create a subset of the information (See Figure 2) and begin by developing a list of the parameters of the harbor resources they feel directly affect the oyster population in a given ORS location. 


\begin{tabular}{|c|c|c|c|c|c|c|}
\hline & Site 1 & Site 2 & Site 3 & Site 4 & Site 5 & Site 6 \\
\hline Latitude & 40.7329743 & 40.7282669 & 40.7057743 & 40.7923690 & 40.7025634 & 40.7914024 \\
\hline Longitude & -74.0117275 & -74.0136909 & -73.9703893 & -73.9282036 & -73.9697795 & -73.9352846 \\
\hline Time & 11:00 a.m. & 10:30 a.m. & 3:00 p.m. & 1:50 p.m. & 1:30 p.m. & 2:17 p.m. \\
\hline Rain & $\begin{array}{l}\text { no rain in the } \\
\text { past } 7 \text { days }\end{array}$ & $\begin{array}{l}\text { Rain in the } \\
\text { past } 72 \text { hours }\end{array}$ & $\begin{array}{l}\text { Rain in the } \\
\text { past } 7 \text { days }\end{array}$ & $\begin{array}{l}\text { Rain in the } \\
\text { past } 24 \text { hours }\end{array}$ & $\begin{array}{l}\text { Rain in the } \\
\text { past } 24 \text { hours }\end{array}$ & $\begin{array}{l}\text { Rain in the } \\
\text { past } 7 \text { days }\end{array}$ \\
\hline Humidity & $70 \%$ - Sunny & $40 \%$ - Sunny & $\begin{array}{l}56 \% \text { - Partly } \\
\text { Cloudy }\end{array}$ & $39 \%$ - Sunny & $74 \%$ - Sunny & $\begin{array}{l}83 \% \text { - Partly } \\
\text { Cloudy }\end{array}$ \\
\hline Wind & $10.35 \mathrm{mph}-\mathrm{S}$ & $4.9 \mathrm{mph}-\mathrm{N}$ & $8 \mathrm{mph}-\mathrm{W}$ & $2 \mathrm{mph}-\mathrm{SE}$ & $11 \mathrm{mph}-\mathrm{SE}$ & $9 \mathrm{mph}-\mathrm{NW}$ \\
\hline Tide & $\begin{array}{l}\mathrm{HT}-4 \mathrm{ft}, \\
\text { LT- } 0.9 \mathrm{ft}\end{array}$ & $\begin{array}{l}\text { HT-5.2ft, } \\
\text { LT- } 0.27 \mathrm{ft}\end{array}$ & $\begin{array}{l}\text { HT- } 4.9 \mathrm{ft}, \\
\text { LT }-0.92 \mathrm{ft}\end{array}$ & $\begin{array}{l}\mathrm{HT}-1.9 \mathrm{ft}, \\
\text { LT }-0.09 \mathrm{ft}\end{array}$ & $\begin{array}{l}\mathrm{HT}-4.6 \mathrm{ft}, \\
\mathrm{LT}-0.41 \mathrm{ft}\end{array}$ & $\begin{array}{l}\mathrm{HT}-6.2 \mathrm{ft}, \\
\text { LT }-0.9 \mathrm{ft}\end{array}$ \\
\hline Current & Ebb Current & $\begin{array}{l}\text { Flood } \\
\text { Current }\end{array}$ & Ebb Current & Ebb Current & Flood Current & Slack water \\
\hline $\begin{array}{l}\text { Current } \\
\text { Speed }\end{array}$ & $\begin{array}{l}1.28611 \\
\text { meters/second }\end{array}$ & $\begin{array}{l}1 \\
\text { meter/second }\end{array}$ & $\begin{array}{l}1 \\
\text { meter/second }\end{array}$ & $\begin{array}{l}3.044 \\
\text { meters/second }\end{array}$ & $\begin{array}{l}1.27 \\
\text { meters/second }\end{array}$ & $\begin{array}{l}4.5 \\
\text { meters/second }\end{array}$ \\
\hline Submerged & 2 meters & 3.11 meters & 1 Meter & 1.5 meters & 1 meter & 145 meters \\
\hline Live Oyster & 50 & 54 & 174 & 29 & 48 & 18 \\
\hline Average Size & $4.24 \mathrm{~mm}$ & $17.65 \mathrm{~mm}$ & $12.91 \mathrm{~mm}$ & $32.39 \mathrm{~mm}$ & $35.52 \mathrm{~mm}$ & $34.78 \mathrm{~mm}$ \\
\hline $\begin{array}{l}\text { Mobile } \\
\text { Traps }\end{array}$ & $\begin{array}{l}\text { shore shrimp, } \\
\text { idotea isopod }\end{array}$ & $\begin{array}{l}\text { black fish, } \\
\text { green crab }\end{array}$ & $\begin{array}{l}\text { tube building } \\
\text { amphipod }\end{array}$ & $\begin{array}{l}\text { gammarid } \\
\text { amphipod }\end{array}$ & $\begin{array}{l}\text { japanese } \\
\text { shore crab, } \\
\text { gammarid } \\
\text { amphipod }\end{array}$ & $\begin{array}{l}\text { black fish, } \\
\text { black-fingered } \\
\text { mud crab }\end{array}$ \\
\hline $\begin{array}{l}\text { Water } \\
\text { Temperature }\end{array}$ & $70 \mathrm{~F}$ & $21.5 \mathrm{C}$ & $64 \mathrm{~F}$ & $22 \mathrm{C}$ & $70.5 \mathrm{~F}$ & $19.00 \mathrm{C}$ \\
\hline $\begin{array}{l}\text { Dissolved } \\
\text { Oxygen }\end{array}$ & $5.50 \mathrm{mg} / \mathrm{L}$ & $6.00 \mathrm{mg} / \mathrm{L}$ & $5.00 \mathrm{mg} / \mathrm{L}$ & $7.60 \mathrm{mg} / \mathrm{L}$ & $3.00 \mathrm{mg} / \mathrm{L}$ & $7.33 \mathrm{mg} / \mathrm{L}$ \\
\hline Salinity & $14.50 \mathrm{ppt}$ & $15.00 \mathrm{ppt}$ & $32.00 \mathrm{ppt}$ & $17.00 \mathrm{ppt}$ & $23.00 \mathrm{ppt}$ & $26.00 \mathrm{ppt}$ \\
\hline $\mathbf{p H}$ & 7.39 & 7.25 & 6.89 & 7.22 & 7.53 & 8.25 \\
\hline Turbidity & $45.00 \mathrm{~cm}$ & $60.00 \mathrm{~cm}$ & $30.00 \mathrm{~cm}$ & $28.00 \mathrm{~cm}$ & $20.00 \mathrm{~cm}$ & $77.20 \mathrm{~cm}$ \\
\hline Ammonia & $3.00 \mathrm{ppm}$ & $5.00 \mathrm{ppm}$ & $5.00 \mathrm{ppm}$ & $1.76 \mathrm{ppm}$ & $1.75 \mathrm{ppm}$ & $0.50 \mathrm{ppm}$ \\
\hline Nitrates & $3.50 \mathrm{ppm}$ & $5.00 \mathrm{ppm}$ & $4.00 \mathrm{ppm}$ & $2.40 \mathrm{ppm}$ & $2.35 \mathrm{ppm}$ & $32.33 \mathrm{ppm}$ \\
\hline
\end{tabular}

Figure 1. Data from the various Oyster Restoration Sites in New York Harbor (June 2017) 


\begin{tabular}{|c|c|c|c|}
\hline & First Choice & Second Choice & Third Choice \\
\hline Average Size of Oyster & $35.52 \mathrm{~mm}$ & $34.78 \mathrm{~mm}$ & 32.39 \\
\hline $\begin{array}{l}\text { Nitrates are less harmful to } \\
\text { oysters than ammonia }\end{array}$ & $2.35 \mathrm{ppm} / 1.75 \mathrm{ppm}$ & $32.23 \mathrm{ppm} / 0.50 \mathrm{ppm}$ & $2.40 \mathrm{ppm} / 1.76 \mathrm{ppm}$ \\
\hline $\begin{array}{l}\text { Oysters are stimulated by high } \\
\text { levels of oxygen }\left(\mathrm{O}_{2}\right)\end{array}$ & $3.00 \mathrm{mg} /$ Liter & $7.33 \mathrm{mg} / \mathrm{Liter}$ & $7.60 \mathrm{mg} / \mathrm{Liter}$ \\
\hline $\begin{array}{l}\text { Oysters need water to pass over } \\
\text { their gills to eat the } \\
\text { phytoplankton }\end{array}$ & 3.27 meters/second & 4.5 meters/second & 3.044 meter/second \\
\hline $\begin{array}{l}\text { High salinity tends to stimulate } \\
\text { oyster growth }\end{array}$ & $23.00 \mathrm{ppt}$ & $26.00 \mathrm{ppt}$ & $17.00 \mathrm{ppt}$ \\
\hline $\begin{array}{l}\text { Oysters thrive at a pH level of } \\
8.1\end{array}$ & 7.53 & 8.25 & 7.22 \\
\hline $\begin{array}{l}\text { High Turbidity Level - reduces } \\
\text { algae population and increases } \\
\left(\mathrm{O}_{2}\right) \text { levels }\end{array}$ & $20.00 \mathrm{~cm}$ & $77.20 \mathrm{~cm}$ & $28.00 \mathrm{~cm}$ \\
\hline Coordinates of the ORS site & $\begin{array}{l}40.7025634 \text { (Latitude) } \\
-73.9697795 \text { (Longitude) }\end{array}$ & $\begin{array}{l}40.7914024 \text { (Latitude) } \\
-73.9352846 \text { (Longitude) }\end{array}$ & $\begin{array}{l}40.7923690 \text { (Latitude) } \\
-73.9282036 \text { (Longitude) }\end{array}$ \\
\hline $\begin{array}{l}\text { Location of the Oyster } \\
\text { Restoration site }\end{array}$ & $\begin{array}{l}\text { East River - Brooklyn } \\
\text { Queens Border }\end{array}$ & $\begin{array}{l}\text { East River at East } 74^{\text {th }} \\
\text { Street Landing }\end{array}$ & $\begin{array}{l}\text { East River - Upper East } \\
\text { Side - Randall's Island }\end{array}$ \\
\hline
\end{tabular}

Figure 2. Subset of Figure 3 with pertinent information for ORS Oyster investigation

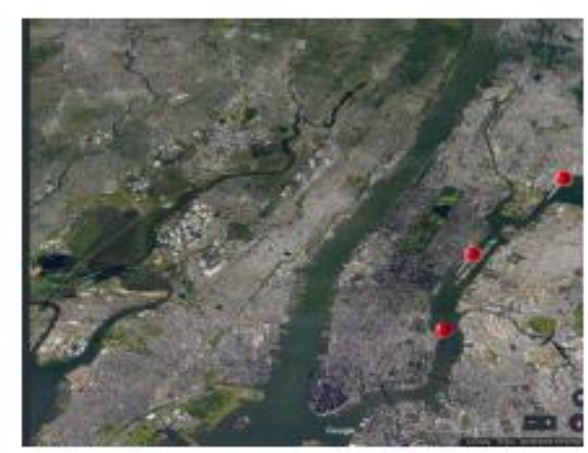

Figure 3. An aerial view of New York with the three Oyster Restoration sites along the East River. Red pushpins indicated selected Oyster Restoration sites. 
Students select their first choice based on the average size of the oysters at the Restorations Station. Then using a combination of self-selected criteria, students decide which site would have the optimal conditions for the oysters to thrive, grow and reproduce. To do this, the students must combine their understanding of previous knowledge about which factors support the oyster restoration station sustainability and growth and the ability of connecting this with pattern recognition. Once the content knowledge has been combined with the unveiling of a pattern in the data, a general rule or interpretation can be applied and a hypothesis (or more than one hypothesis) can be formulated. The interpretation of the digital information will then lead to an algorithm design to solve the problem. One of the findings by Thaiposri \& Wannapiroon (2015) found that enhancing students' critical thinking skills through inquiry-based learning activities that use cloud computing is appropriate for application to real practice. It also helps student to develop the knowledge and skills that they will require to achieve success in the information age.

Referencing the four stages of computational thinking in the middle school science performance expectation (MS-LS2-1):

- Decomposition - Breaking a problem into manageable chunks to make it easier to solve.

Of the 22 parameters in the spreadsheet, students will be asked to select the parameters that would affect the resources needed by the oysters to survive and thrive (e.g., ammonia and nitrate concentrations).

- Pattern Recognition - Seeing a generalized view of the problem; trends or regularities in the data (ammonia/nitrate ratio at various ORS).

- Abstraction - Finding the general principles that generate the patterns in the data. (E.g., location, pH, current speed, dissolved oxygen)

- Algorithm design - Developing the step-by-step instructions to solve this problem and others like it. (Develop a schema of the selected ORS to illustrate the effects of the resources in the estuary on the growth and development of the oyster population).

\subsection{The 5E Model Lesson Plan}

The BOP-CCERS curriculum has been developed by incorporating the Biological Sciences and Curriculum Study (BSCS) 5E Instructional Model (Bybee, et al., 2006) with the STEM core content found in the restoration science units and the New York State P-12 Science Learning Standards. The BSCS 5 E Instructional Model was developed in 1987 and has its basis in the constructivism learning theory. Based on the premise that knowledge is constructed by the learner and relies on personal experiences (Kemp, 2011), this learning theory was made famous through the works of Lev Vygotsky (1996). Other researchers built upon his work and furthered that problem-based learning is the activation of the learner's prior knowledge, with the learner creating an action plan for problem solving by making connections and thinking critically (Schmidt, Rotgans \& Yew, 2011). Also needed is the learner's ability to integrate knowledge across disciplines (Lee \& Kamisah, 2015) and use computers as tools for the formation of information and not just its consumption (Mellis, Carvalho \& Thompson, 2014).

3.2.1 Example of the 5E Lesson Plan

Grade/ Grade Band: 6 - 8

\section{Brief Lesson Description:}

This task is intended for students at the middle school level and would best fit within an instructional unit on the cycling of Earth's materials. The task involves material covered in 6th grade computer science standards, $6^{\text {th }}$ grade math standards and the MS-ESS2-1 NGSS. Because the interpretation of the data is essential for the development and explanation of the nitrogen cycle model, checks for understanding (i.e., formative assessment) should be administered frequently throughout the lesson.

\footnotetext{
Performance Expectation(s):

MS-LS2-1. Analyze and interpret data to provide evidence for the effects of resource availability on organisms and populations of organisms in an ecosystem.

Specific Learning Outcomes:

- Students will be able to select a focused subset of data from a much larger set of available data.
}

to study nitrogen throughout our estuary

\section{Lesson \# $\underline{8}$ in a series of $\underline{10}$} lessons 
- Students will be able to organize and present that data through the use of decomposition, pattern recognition, data analysis and algorithmic design in a way that highlights interesting patterns or raises interesting questions and possible solutions.

- Students will use mathematical, computer science and computational thinking skills to solve a real-world scientific dilemma. [Knowing that there are many right answers to problem solving]

\begin{tabular}{|c|c|c|}
\hline \multicolumn{3}{|l|}{ Narrative / Background Information } \\
\hline \multicolumn{3}{|c|}{$\begin{array}{l}\text { Prior Student Knowledge: } \\
\text { 1. The nitrogen cycle application to New York City [Lesson 1] } \\
\text { 2. Comparison of nitrogen cycle in the estuary and the classroom tank [Lesson 2] } \\
\text { 3. Monitoring of the ammonia and nitrate levels in the classroom tank [Lesson 3] } \\
\text { 4. Molecular structure of compounds containing nitrogen [Lesson 4] } \\
\text { 5. Acceptable levels of ammonia and nitrates to support life in the tank [Lesson 5] } \\
\text { 6. Nitrogen transformations in the tank [Lesson 6] } \\
\text { 7. Neighborhood Nitrogen Mapping [Lesson 7] }\end{array}$} \\
\hline $\begin{array}{l}\text { Science \& Engineering Practices: } \\
\text { Analyzing and Interpreting Data } \\
\text { Analyzing data in 6-8 builds on } \\
\text { K-5 experiences and progresses } \\
\text { to extending quantitative } \\
\text { analysis to investigations, } \\
\text { distinguishing between } \\
\text { correlation and causation, and } \\
\text { basic statistical techniques of } \\
\text { data and error analysis. } \\
\text { Analyze and interpret data to } \\
\text { provide evidence for } \\
\text { phenomena. }\end{array}$ & $\begin{array}{l}\text { Disciplinary Core Ideas: } \\
\text { LS2.A: Interdependent Relationships in } \\
\text { Ecosystems } \\
\text { - Organisms, and populations of } \\
\text { organisms, are dependent on their } \\
\text { environmental interactions both } \\
\text { with other living things and with } \\
\text { nonliving factors. } \\
\text { - In any ecosystem, organisms and } \\
\text { populations with similar } \\
\text { requirements for food, water, } \\
\text { oxygen, or other resources may } \\
\text { compete with each other for limited } \\
\text { resources, access to which } \\
\text { consequently constrains their } \\
\text { growth and reproduction. } \\
\text { - Growth of organisms and } \\
\text { population increases are limited by } \\
\text { access to resources. }\end{array}$ & $\begin{array}{l}\text { Crosscutting Concepts: } \\
\text { Cause and Effect } \\
\text { - Cause and effect } \\
\text { relationships may be used to } \\
\text { predict phenomena in natural } \\
\text { or designed systems. }\end{array}$ \\
\hline
\end{tabular}

Computer Science Standards Addressed:

CSTA K-12 CS Standards, 2017:

2-DA-08, Grades 6-8:

Collect data using computational tools and transform the data to make it more useful and reliable.

2-DA-09, Grades 6-8:

Refine computational models based on the data they have generated.

2-AP-10, Grades 6-8:

Use flowcharts and/or pseudo-code to address complex problems as algorithms.

\section{Possible Preconceptions/Misconceptions:}

Students may have the preconceived idea that the New York Harbor estuary is uniform in the composition of its water and not realize that the numerous and varied geographical and urban surroundings contribute to the water quality in a given area. Students may be confused and not realize that there are structural differences between ammonia, nitrates and nitrites and these structural differences influence the characteristics of each of the compounds. 


\section{Materials Required for This Lesson/Activity}

1. Google Map of the New York Harbor Estuary

2. Access to the BOP Platform

3. Access to spreadsheet and graphing applications such as Excel

\section{LESSON PLAN - 5-E Model}

ENGAGE: Opening Activity - Access Prior Learning / Stimulate Interest / Generate Questions:

1. Students examine a map of the estuary (you can use Google Map street view and/or satellite view), and make predictions:

○ "Where do you imagine you would find higher and lower levels of ammonia and nitrates in our estuary? Why?"

○ "What questions come up as you think about this?"

2. Make note of students' questions and predictions.

\section{EXPLORE: Lesson Description - Materials Needed / Probing or Clarifying Questions:}

1. Students login to www.platform.bop.nyc and navigate to the Dashboard page. Look at the map of ORS locations. Students identify an area of interest to them. Remind them to:

○ Zoom in!

2. Look closely at nooks and crannies in the shape of the shoreline.

On a piece of paper, students write down the names of the ORSs in the places that interest them.

- Example: I wanted to look at some nitrogen data in an area that doesn't flush as well as other parts of the estuary. So I located "IS 288 ORS", near the mouth of Coney Island Creek.

3. Students navigate to the Data page and select the Download tab.

Under "Filter the Expeditions" students search for the places and times that interest them.

4. Example: Under "Filter the Expeditions" I typed "IS 288 ORS" into the ORS Name field.

Under "Select Parameters to Display" students click on the types of data that interest them.

- Example: I clicked on the following boxes. I chose them because I thought that flushing might have something to do with currents, and I thought that nitrogen might have something to do with dissolved oxygen.

Tidal current

Dissolved oxygen
Surface current Ammonia

Nitrates

6. Under "View or Download Data" they click Download Results.

7. The file downloads, and they open it in Excel or a very similar spreadsheet and graphing application.

8. Students "clean up" the data.

- Example: In the data downloaded, the expeditions were listed by name, and I wanted the dates. So I opened a new tab to the Data page and repeated steps 1,2 and 3. That way I could see each expedition on a tile with its name and date. I typed the dates into my Excel sheet.

I made the display look a little nicer by deleting rows I didn't need, bolding some things, etc.

\section{EXPLAIN: Concepts Explained}

Students present their findings to small groups or to the whole class, explaining:

- Why they selected the places they selected?

- Why they looked at the parameters they selected?

- What they did to 'clean up' their data, and why? 
- What the data conveys to them?

\section{ELABORATE: Applications and Extensions:}

The small groups or full class have a discussion focused on:

- What interested patterns do we notice in the data presented here?

- What questions do we have, look at the data presented here?

- How might we learn more by looking at the same data a different way?

- How might we learn more by looking at more or different data?

\section{EVALUATE:}

Students choose an issue from the class discussion on which to follow up. They go back into the Digital Platform for more data or different data, and/or they represent their data in a different way. Students will have the opportunity to communicate their findings and present various possibilities to rectify the excess ammonia in a given area.

Elaborate Further / Reflect: Enrichment:

Students develop ideas for science research topics that will be explored and presented at the BOP Science Symposium

Figure 4. The Billion Oyster Project - Nitrogen Cycle Lesson Plan using the 5E Teaching Strategy

\section{Discussion}

$21^{\text {st }}$ Century skills emphasize the need for learning to be holistic, integrated, connected, skillful, relevant, adaptable, student-centered, project-based and authentic (McLeod, Bathon \& Richardson, 2011). The environment in which we now live is driven by technology as evidenced by our access to an abundance of information. Coupled with advances in technological tools, today's students must be able to demonstrate a range of purposeful and critical thinking skills. In a study done by DeLuca and Lari (2011) it is suggested that the level of higher order thinking is affected by the relevance of the social issue situated within systemic data collection. The results of the study suggest the importance of a scientist's personal reflection combined with the application of conceptual knowledge to authentic problem solving.

Learning occurs best when students engage in finding real solutions to real-world problems. The ability to recognize the social issue through the computational thinking framework enables students to extend their thinking to include applying the concepts and synthesizing them for a deeper understanding. Students whose learning abounded with opportunities for "computational doing" would evidence a more fluid kind of problem solving. These students would understand that "problems can be solved in multiple ways", have "a tolerance for ambiguity and flexibility" and have "reasonable expectations about the prospect of producing a working solution" (Barr \& Stephenson, 2011). When teachers introduce student to information, knowledge and skills in the context of problem solving rather than simply as facts, they are much more likely to retain and apply them to problems in new situations in the future. Science involves inquiring into one's own world and so science should utilize the local community and student interest (Laughter \& Adams, 2012). If knowledge and skills being taught are supportive of problem-solving efforts outside of the classroom then the goal of developing $21^{\text {st }}$ Century Skills has been met (Fortus, Krajcikb, Dershimerb, Marx, \& Mamlok-Naamand, 2005). At the intersection of theory and practice, the individual learner should be given the opportunity to explore and discover new knowledge though problem-solving (Bruner, 1966).

\section{Conclusion}

21st Century learning, combined with constructivism is student-centered and geared toward a deeper understanding of content with which the learner can work creatively (Sawyer, 2006: McLeod, Bathon \& Richardson, 2014). Computer supported collaborative learning focuses on pedagogical approaches that incorporate computers for interactive learning so that the student can contribute to the development of new knowledge (Stahl, 2006). In summation, there is a synergy created by combining the skills acquired in computational thinking, the three dimensional learning acquired from the NYSED Science Learning Standards and access to the data-rich BOP Platform. Middle school students in the Billion Oyster Project Curriculum and Community Enterprise for Restoration Science classrooms in the New York City public schools have an enhanced learning experience that improves student engagement and increases both knowledge and skills acquisition. The hands-on, active, problem based approach to learning follows the constructivist model (Freeman, et al., 2014). Studies indicate that student performance increased with active learning, especially across the STEM disciplines (Ah-nam \& Osman, 2017). The 
design model for the Billion Oyster Project-Curriculum and Community Enterprise for Restoration Science in New York Harbor (BOP-CCERS) lends itself to the integration of real-world, data-driven computational thinking.

\section{References}

Allan, W., Coulter, B., Denner, J., Erickson, J., Lee, I., Malyn-Smith, J., \& Martin, F. (2010). Computational thinking for youth. White Paper for the ITEST Small Working Group on Computational Thinking (CT).

Ah-Nam, L., \& Osman, K. (2017). Developing $21^{\text {st }}$ Century skills through a constructivist-constructionist learning environment. K-12 STEM Education, 3(2), 205-216.

Barr, D., Harrison, J., \& Conery, L. (2011, March/April). Computational Thinking: A Digital Age. Learning and Leading with Technology, 19-23.

Barr, V., \& Stephenson, C. (2011). Bringing computational thinking to K-12: What is involved and what is the role of the computer science education community? ACM Inroads, 2(1), 48- 54.

Birney, L., \& McNamara, D. (2017a). Authentic Community Based Learning in New York City: An Holistic Model using the Billion Oyster Project and Community Enterprise for Restoration Science. Journal of Education and Human Development, 6(4), 1-15. https://doi.org/10.15640/jchd.v6n4a1

Birney, L., \& McNamara, D. (2017b). Science Curriculum Content for Real World Application, International Journal of Education and Social Science, 4(6). Retrieved from www.ijessnet.com

Borgman, C. (2007). Scholarship in the Digital Age: Information, Infrastructure, and the Internet. MIT Press. Retrieved from http://www.jstor.org/stable/j.ctt5hhbk7

Brennan, K., \& Resnick, M. (2012). Using artifact-based interviews to study the development of computational thinking in interactive media design. Paper presented at annual American Educational Research Association meeting, Vancouver, BC, Canada.

Bruner, J.S. (1986). Toward a Theory of Instruction. Cambridge, MA; Harvard University Press.

Bybee, R.W., Taylor, J.A., Gardner, A., Van Scotter, P., Powell, J., Westbrook, A., \& Landes, N. (2006). The BSCS 5E Instructional Model: Origins and Effectiveness. Colorado Springs, CO: Biological Sciences Curriculum Series.

Calabrese Barton, A., \& Berchini, C. (2013). Becoming an insider: Teaching science in urban setting. Theory into Practice, 52(1), 21-27.

Cassel, R.N., \& Kolstad, R. (1998). The critical job-skills requirements for the 21st century: Living and working with people. Journal of Instructional Psychology, 25(3), 176-180.

Computer Science Teachers' Association. (2017). Computer Science Standards (CSTA K-12). Retrieved from http://www.csteachers.org/page/standards

Curzon, P., Dorling, M., Ng, T., Selby, C., \& Woollard, J. (2014). Developing computational thinking in the classroom: A framework. Draft policy document, Computing at School, June 2014.

DeLuca, V.W., \& Lari, N. (2011). The GRID C Project: Developing Students' Thinking Skills in a Data-Rich Environment. Journal of Technology Education, 23(1). https://doi.org/10.21061/jte.v23i1.a.2

Fortus, D., Krajcik, J., Dershimer, R. C., Marx, R. W., \& Mamlok-Naaman, R. (2005). Design-Based Science and Real-World Problem-Solving. International Journal of Science Education, 27, 855-879. https://doi.org/10.1080/09500690500038165

Freeman, S., Eddy, S.L., McDonough, M., Smith, M.K., Okoroafor, N., Jordt, H., \& Wenderoth, M.P. (2014, June 10). Active learning increases student performance in science, engineering and mathematics. PNAS, 111(23) 8410-8415. https://doi.org/10.1073/pnas.1319030111

Google Earth. Retrieved June 10, 2018, from https://earth.app.goo.gl/GhfXM

Hey, T., \& Trefethen, A.E. (2005). Cyber-infrastructure for e-Science. Science, 308(5723), 817-821. https://doi.org/10.1126/science.1110410

Kemp, S. (2011). Constructivism and problem-based learning. Singapore: Temasek Polytechnic, Learning Academy.

Kules, B. (2016). Computational thinking is critical thinking: Connecting to university discourse, goals, and learning outcomes. Proceedings of the Association for Information Science and Technology, 53(1), 1-6. 
Laughter, J.C., \& Adams, A.D. (2012). Culturally relevant science teaching in middle school, Urban Education, 47(6), 1106-1134. https://doi.org/10.1177/0042085912454443

Lee, C.H., \& Osman, K. (2015). An interdisciplinary approach for biology, technology, engineering \& mathematics (BTEM) to enhance $21^{\text {st }}$ century skills in Malaysia. K-12 STEM Education, 1(3), 137-147.

McLeod, S., Bathon, J.M., \& Richardson, J.W. (2011). Studies of technology tool usage are not enough. Journal of Research in Leadership Education, 6(5), 228-297.

Mellis, S., Carvalho, L., \& Thompson, K. (2014). Applying $21^{\text {st }}$ Century Constructivist Learning Theory to Stage 4 Design Projects. AARE Conference Paper, January 2014.

Morris, B.J., Masnick, A.M., Baker, K., \& Junglen, A. (2015). An Analysis of Data Activities and Instructional Supports in Middle School Science Textbooks. International Journal of Science Education, 37(16), 2708-2720. https://doi.org/10.1080/09500693.2015.1101655

NGSS Lead States. (2013). Next Generation Science Standards: For States, By States. Washington, DC: The National Academies Press.

National Research Council. (2012). A Framework for K-12 Science Education: Practices, Crosscutting Concepts, and Core Ideas. Washington, DC: The National Academies Press.

New York City Department of Education. (2018). Equity and Excellence for All - Computer Science for All. Retrieved from http://cs4all.nyc/2018/03/21/about-cs4all/

New York State Department of Education. (2016). New York State P-12 Science Learning Standards. Retrieved from http://www.p12.nysed.gov/ciai/mst/sci/documents/p-12-science-learning-standards.pdf

Organization for Economic Cooperation and Development. (2015). PISA 2015 Results in Focus, OECD. Retrieved June 2018, from https://www.oecd.org/pisa/pisa-2015-results-in-focus.pdf

Partnership for $21^{\text {st }}$ Century Learning. (2016). Framework for $21^{\text {st }}$ Century Learning. Washington, D.C. Retrieved from http://www.p21.org/storage/documents/docs/P21_framework_0816.pdf

PCAST STEM Undergraduate Working Group. (2012). Engage to Excel: Producing One Million additional college graduates with degrees in science, technology, engineering and mathematics, Eds. Gates, S.J., Handelman, J., Lepage, G.P. \& Mirkin, C. Office of the President, Washington.

Sawyer, R.K. (2006). The Cambridge Handbook of the Learning of Sciences. New York,: Cambridge University Press.

Schmidt, H.G., Rotgans, J.I., \& Yew, E.H.J. (2011). The process of problem-based learning: What works and why. Medical Education, 45(8), 792-806. https://doi.org/10.1111/j.1365-2923.2011.04035.x

Sengupta, P., Kinnebrew, J.S., Basu, S., Biswas, G., \& Clark, D. (2013). Integrating Computational thinking with K-12 science education using agent-based computation: A theoretical framework. Education and Information Technologies, 18, 351. https://doi.org/10.1007/s10639-012-9240-х

Sneider, C., Stephenson, C., Schafer, B., \& Flick, L. (2014, November). Exploring the Science Framework and the NGSS: Computational Thinking in Elementary School Classrooms. Science Scope, 10-17.

Sobel, D. (2005). Place-based education: Connecting classrooms and communities. Great Barrington, MA: The Orion Society.

Stahl, G. (2006). Group Cognition: computer support for building collaborative knowledge; Ch. 19: Can collaborative groups think?. MIT Press, Cambridge, MA

Thiaposri, P., \& Wannapiroon, P. (2015). Enhancing students' critical thinking skills through teaching and learning by inquiry-based learning activities using social network and cloud computing. Procedia-Social and Behavioral Sciences, 174, 2137-2144.

Trilling, B., \& Fadel, C. (2009). 21 st Century Skills: Learning for Life in Our Times. San Francisco, CA: John Wiley $\&$ Sons.

United States. National Commission on Excellence in Education. (1983). A nation at risk: the imperative for educational reform: a report to the Nation and the Secretary of Education. United States Department of Education. Washington, D.C.: The Commission: [Supt. of Docs., U.S. G.P.O. distributor]. 
Vygotsky, L.S. (1978). Mind and Society: The development of higher psychological processes. Cambridge, MA: Harvard University Press.

Weintrop, D., Beheshti, E., Horn, M., Kai, O., Jona, K., Trouille, J., \& Wilensky, U. (2016). Defining Computational Thinking for Mathematics and Science Classrooms. Journal of Science Education and Technology, 25(1), $127-147$.

Wing, J. M. (2006, March). Computational Thinking. Communications of the ACM, 49(3), 33-35.

\section{Note}

Note 1. Waterford Technologies, (2/22/2017), https://www.waterfordtechnologies.com/big-data-interesting-facts/ 